\title{
Optimization of Pre Cast Post Tensioned Concrete Deck Type Box Girder Bridge
}

\author{
Nagaraj Nayak ${ }^{1}$, Dr. S. S. Bhavikatti ${ }^{2}$ \\ ${ }^{1}$ PG Scholar, Department of Civil and Environmental Engineering, K.L.E Technological University Hubballi, Karnataka, India \\ ${ }^{2}$ Professor, Department of Civil and Environmental Engineering, K.L.E Technological University Hubballi, Karnataka, India
}

\begin{abstract}
Bridge is a structure which provides passage over an obstacle without obstructing the way beneath. PSC bridges are adopted for span greater than $20 \mathrm{~m}$. In present study a two lane simply supported Box Girder Bridge is designed for moving loads as per Indian Road Congress loadings (IRC:6-2014) prestressed concrete code (IS: 1343-2012) and IRC: 18-2000 specifications. The cable is prestressed with parabolic tendons.Deck slab is designed by working stress method and girder is designed by limit state method. A computer program is developed in C-programming language to design the deck slab and PSC Box-girder. Optimization is carried out by using sequential linear programming with improved move limit method.
\end{abstract}

Keywords: Pre Stressed Concrete, Deck slab, Box Girder, C-Program, Optimization

\section{Introduction}

Bridge is a kind of structure which provides the passage over an obstacle without obstructing the way beneath. Bridges can be used as the passage of railway, road way and even transfer of fluids. Prestressed concrete bridges will be used in the longer and moderate span bridge construction.For the $30 \mathrm{~m}$ to $70 \mathrm{~m}$ span single or multi cell box-girder bridge is recommended.Pre-cast Post-tensioned concrete deck type box girder bridges are widely used inthe highway bridges. In these bridges top flange act as cross girder.

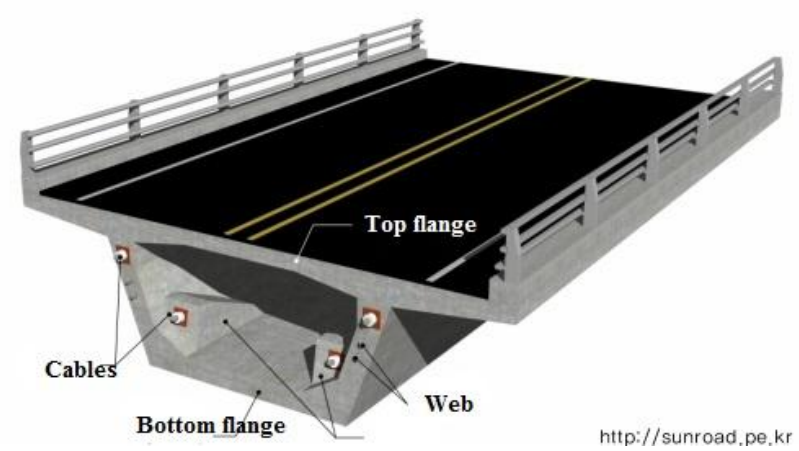

Figure 1: Typical box girder

\subsection{Advantages of prestressed concrete bridges}

Prestressed concrete offers great technical advantages in comparison with other construction, such as reinforced concrete and steel. Some of them are listed below,

- The structure will be slender since steel and concrete of high strength are used.

- In prestressed concrete bridges even higher cracks can be avoided by designing it as class I type in which tensile stress is negligibly small.

- Maintenance cost of prestressed concrete bridge is negligible as compare to steel bridges.

\subsection{IRC Tracked Vehicle For Live Loads}

The live load to be considered for bridge design, particularly for roadways are specified in IRC:6-2014. The various differentiating parameters between different IRC vehicles are, loading, ground contact area and side clearance.

The various IRC vehicles are specified in IRC: 6 - 2014,

(a) IRC class AA

- Tracked, with loading of 70 tonnes.

- Wheeled, with loading of 20 tonnes for single axles \& 40 tonnes for two axles

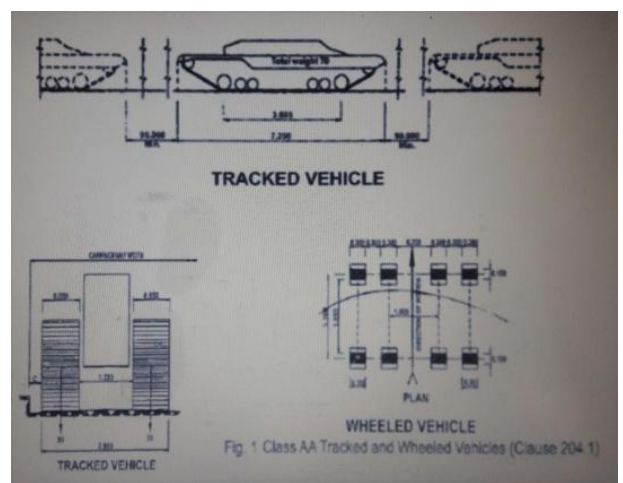

Figure 2: Tracked vehicle of IRC class AA

\subsection{Need for optimization}

There are many acceptable designs for a single design problem but among all the acceptable designs, one which is most economical will satisfy both structural engineering standards as well as economical need.The act of obtaining the best results under given circumstances is called optimization. Optimization has got huge scope in structural engineering. In this project the cost optimization of pre-cast post tensioned concrete deck type box-girder bridge is carried out.

\subsection{Objectives}

The various objectives to be achieved are, 


\section{International Journal of Science and Research (IJSR) \\ ISSN (Online): 2319-7064}

Index Copernicus Value (2015): 78.96 | Impact Factor (2015): 6.391

- To employ the sequential linear programming optimization technique for optimum design of pre-cast post-tensioned concrete box girder.

- To provide the bases for selection of economical dimension in designing of pre-cast post-tensioned concrete deck type box -girder to the structural engineer.

- To study the effect of change in grade of concrete and steel on economy of the pre-cast post-tensioned concrete deck type box -girder

- To carry out the parametric study on effect of cost ratio on optimum design

\section{Design Requirements}

Prestressed concrete is a type of concrete in which appropriate quantity of internal stress is provided in such way that stresses due to external loads will be reduced to required quantity Prestress is generally introduced by the method of tensioning of the steel reinforcement.

\subsection{Check for ultimate moment and shear}

\section{Ultimate moment check}

The strength of prestressed concrete structure will be checked against the failure conditions. The ultimate moment is calculated as follows:

Ultimate moment with reference to clause 12 P No 20 IRC: $18-2000$

Ultimate moment under normal condition $=1.25 \mathrm{DLBM}+2$ SDLBM + 2.5LLBM

Ultimate moment under severe condition $=1.5 \mathrm{DLBM}+2$ SDLBM + 2.5LLBM

where,

DLBM=Dead Load Bending Moment

SDLBM=Superimposed Dead Load Bending Moment

LLBM=Live Load Bending Moment

Failure by yielding of steel with reference clause 13(i) P No 20 IRC : $18-2000$

Mulim=0.9xdbxApxfup

where,

Mulim=Ultimate moment due to yielding of steel

$\mathrm{db}=$ Depth of the box girder from the extreme compression edge to the center of gravity of the tendons.

Ap $=$ Total area for high tensile steel tendon.

fup $=$ The ultimate tensile strength for steel.

Failure by crushing of concrete with reference clause 13(ii) $\mathrm{P}$

$\begin{array}{lllll}\text { No } & 21 & \text { IRC } & 18 & -\end{array}$

Muc $=0.176 * b w * d^{2} * f c k 1+\left(\frac{67}{100}\right) * 0.8 x(b f-b w) *$ $\left(d g-\frac{d f}{2}\right) x * d f * f c k 1$

where,

Muc=Ultimate moment due to crushing strength of concrete bw $=$ the width of web of a box girder

$\mathrm{d}=$ Depth of the box girder from the edge of maximum compression to the center of gravity of the tendons.

$\mathrm{fck} 1=15 \mathrm{~cm}$ cubes characteristic compressive strength at 28 days.

bf $=$ The width of top flange of box girder

$\mathrm{t}=$ Thickness of flange of a box girder.

$\mathrm{df}=$ Depth of top flange

\section{Check for ultimate shear}

Ultimate shear resistance of concrete is considered in flexure for the cracked and un cracked and lesser value will be taken. If required shear reinforcement is provided.

Ultimate shear with reference to clause 12 P No 20 IRC : 18 $-2000$

Ultimate shear under normal condition $=1.25 \mathrm{DLSF}+2$ SDLSF + 2.5 LLSF

Ultimate shear under severe condition $=1.5 \mathrm{DLSF}+2$ SDLSF + 2.5 LLSF

where,

DLSF=Dead Load Shear Force

SDLSF=Superimposed Dead Load Shear Force

LLSF=Live Load Shear Force

Ultimate shear resistance of a section un-cracked in flexure clause 14.1.2.1 P No 22

$V c W=0.67 * b W * h * \sqrt{f t^{2}+0.8 * f c p * f t}+n l * P s f * \sin \theta$

Where,

bw $=$ Width of the rib of box girder

$\mathrm{d}=$ Overall depth of the box girder.

$\mathrm{ft}=$ Maximum principal tensile stress which is given by $0.24 \sqrt{f c k}$

fcp $=$ Positive prestress produces compressive stress at centroid axis.

\section{Shear reinforcement}

With reference to clause 14.1.4 P No 24 IRC : $18-2000$

- If $\mathrm{V}<\mathrm{Vc} / 2$

No shear reinforcement is required.

- If $\mathrm{V}>\mathrm{Vc} / 2$

Minimum shear reinforcement is required.

- If $\mathrm{V}>\mathrm{Vc}$

Shear reinforcement shall be provided.

Sv/Asv $=(0.87 \mathrm{fyvdt}) /(\mathrm{V}-\mathrm{Vc})$

where,

$\mathrm{Vc}=$ Concrete carrying shear force in $\mathrm{kN}$.

fyv $=$ Yield strength given by shear reinforcement or proof stress of 0.2 per cent which should be taken within 415 $\mathrm{MPa}$.

Asv $=$ Cross-sectional area of link with two legs in N/mm2.

$\mathrm{Sv}=$ The link spacing with the length of member

$\mathrm{dt}=$ Depth from the top of compression fiber to thelongitudinal bars of diameter not less than the link bar over whichthe link will pass or to the centroid of the tendons, whichever is greater

\section{Design Problem}

To facilitate development of computer program and checking the program developed the following design is considered.

\section{Preliminary data:}

Clear span $\mathrm{Lc}=40 \mathrm{~m}$

Width of road way $(\mathrm{cw})=7.50 \mathrm{~m}$

Depth of wearing coat $(\mathrm{dwc})=80 \mathrm{~mm}$

Length of overhang from face of girder (lo) $=1.25 \mathrm{~m}$

Diameter for the short span in slab dia $2=12 \mathrm{~mm}$

Diameter for the long span in slab dial $=10 \mathrm{~mm}$ 


\section{International Journal of Science and Research (IJSR)}

ISSN (Online): 2319-7064

Index Copernicus Value (2015): 78.96 | Impact Factor (2015): 6.391

Density of concrete $\mathrm{pc}$

$=25 \mathrm{kN} / \mathrm{m} 3$ Density of wearing coat $\rho w c=22 \mathrm{kN} / \mathrm{m} 3$

The profile of the tendon parabolic in nature is considered for design.

Permissible stress in Prestressing concrete Fck1= $60 \mathrm{MPa}$

Permissible stress in concrete Fck2 $=20 \mathrm{MPa}$

Permissible stress in steel Fy= $415 \mathrm{MPa}$

Allowable stress in P S Concrete:

$\mathrm{fci}=0.8 \mathrm{fck}=48 \mathrm{MPa}, \quad$ As per IRC: $18-2000$

$\mathrm{fct}=0.45 \mathrm{fci}=21.6 \mathrm{MPa}$

$\mathrm{fcw}=0.33 \mathrm{fck}=19.8 \mathrm{MPa}$

$\mathrm{ft}=1 / 10$ th of $\mathrm{fct}=0 \mathrm{MPa}$, ftw $=0$ As referenced by

IS:1343-2012

$\mathrm{Ec}=5000 \sqrt{\mathrm{fck}}=38.72 \mathrm{kN} / \mathrm{m} 2$

Duct diameter $\mathrm{dd}=100 \mathrm{~mm}$

Clear cover $\mathrm{dc}=50 \mathrm{~mm}$

Allowable stresses in prestressing steel:

Ultimate tensile stress in steel Fp $=1862 \mathrm{MPa}$,

Loss ration in P.S concrete $\mathrm{nl}=0.85$

Modulus of elasticity in steel $\mathrm{E}=2 \times 105 \mathrm{MPa}$

Live load IRC Class AA tracked as Per IRC 6-2014

$\mathrm{W} 1=\mathrm{W} 2=$ one wheel of tracked vehicle load $=350 \mathrm{kN}$

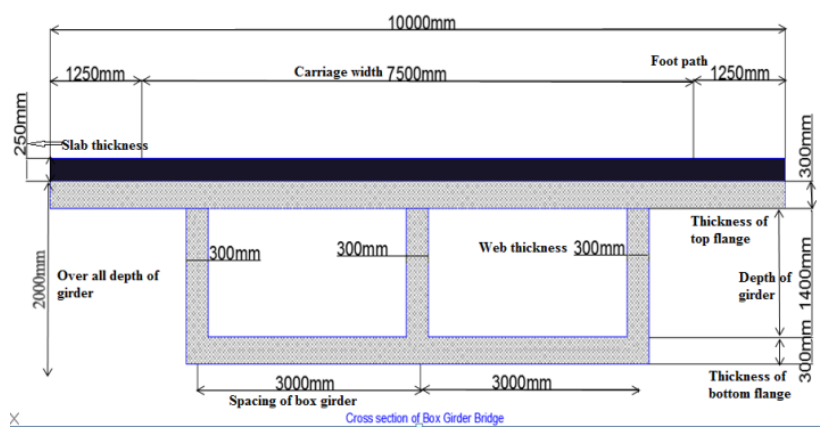

Figure 3: cross section of box girder

Final values of design forces obtained are tabulated as below.

Table 1: For design forces

\begin{tabular}{|c|c|c|}
\hline Sl.No & Bending Moment $(\mathrm{kN}-\mathrm{m})$ & Shear Force $(\mathrm{kN})$ \\
\hline 1. & DLBM $=15536$ & DLSF $=1553$ \\
\hline 2. & LLBM $=3785.06$ & LLSF $=484$ \\
\hline & Total $=2.5 *$ LLBM+1.5*DLBM & Total $=2.5 *$ LLSF+1.5*DLSF \\
\hline 3. & TDLBM $=32802.0$ & TDLSF $=3539.5$ \\
\hline
\end{tabular}

where,

DLBM=Dead load bending moment in $\mathrm{kN}-\mathrm{m}$

LLBM=Live load bending moment in $\mathrm{kN}-\mathrm{m}$

$\mathrm{DLSF}=$ Dead load shear force in $\mathrm{kN}$

LLSF=Live load shear force in $\mathrm{kN}$

TDLBM=Total design load bending moment in $\mathrm{kN}-\mathrm{m}$

$\mathrm{TDLSF}=$ Total design load shear force in $\mathrm{kN}$

\subsection{Design Program}

The problem is automated by writing a program in " $\mathrm{C}$ " language which is user friendly and edible for design of deck slab and PSC box-girder. But the program scope is limited to design for particular class of loading. The reinforcement details are clearly specified.

\subsection{Mathematical formulation of optimization problem}

Mathematical form of general optimization problem involves in finding the variable vector,

$\mathrm{x}=(\mathrm{x} 1, \mathrm{x} 2, \mathrm{x} 3 \ldots \ldots \mathrm{xn})^{T}$

tominimize the objective function $\mathrm{Z}=\mathrm{f}(\mathrm{x})$ subjected to constraints:

$\operatorname{gj}(\mathrm{x}) \leq 0$, where $\mathrm{i}=1,2 \ldots \mathrm{m}$

where,

$\mathrm{x}=$ Design vector with $\mathrm{n}$-dimensions.

$\mathrm{Z}=$ Objective function.

$\mathrm{gj}(\mathrm{x})=$ Inequality constraints of $\mathrm{m}$ number.

There are three basic elements required to formulate the optimization problem mathematically they are design variables, objective functions and constraints.

\subsection{Design variables}

The design variables are,

- Over all depth of girder

- Depth of top flange

- Depth of bottom flange

- Thickness of web girder

\subsection{Objective Function}

The objective function considered is the minimization of material cost and is assembled as shown below,

Fcost $=$ Qconc $*$ Cconc + Qsteel $*$ Csteel + Qcable $*$ Ccable where,

Fcost=Optimum cost of girder in lakhs

Qconc $=$ Quantity of concrete in $\mathrm{m} 3$

Cconc $=$ Cost of concrete in $\mathrm{Rs} / \mathrm{m} 3$

Qsteel=Quantity of steel in $\mathrm{m} 3$

Csteel $=$ Cost of steel in Rs/m3

Qcable $=$ Quantity of cable (prestressing steel) in $\mathrm{m} 3$

Ccable $=$ Cost of cable (prestressing steel)inRs $/ \mathrm{m} 3$

\subsection{Cost Consideration}

The various cost to be considered are from Schedule of Rates (SR) of latest version and the region in which the site belongs to, for example if a site is in Hubballi then we need to refer schedule of rates $2016-2017$ publicworks, ports \& inlandwater transport department, north zone, Dharwad.

The various cost considered are, For M40 grade of concrete cost is $6,000 \mathrm{Rs} / \mathrm{m} 3$, Cost of steel (Fe415 TMT) is 40,000 per Tonne, Cost of prestressing steel is $1,25,000$ per Tonne

Note: The above cost include cost of material, transportation and labor cost.

The objective function can be written as, For M40 grade of concrete and Fe 415 steel

Fcost $=$ Qconc $* 6000+$ Qsteel $* 40000+$ Qcable $* 125000$

\subsection{Constraints}

The various condition that need to be satisfied are related to section properties, stress at transfer, stress at working load 


\section{International Journal of Science and Research (IJSR) \\ ISSN (Online): 2319-7064}

Index Copernicus Value (2015): 78.96 | Impact Factor (2015): 6.391

stage, check for ultimate flexural strength and various side constraints that need to be satisfied as per IRC codes, and the condition to find the reaction factor (Courbon's theory).

Behavior constraints

- $\mathrm{Zb}=\left[\frac{\mathrm{Mq}+[(1-\mathrm{n}) * \mathrm{Mg}}{\mathrm{fbr}}\right] \leq Z$ provided

i. $\mathrm{Zb}=\left[\frac{\text { Required section modulus }}{\text { Section modulus of provided section }}-1\right] \leq 0$

- $\frac{\text { Etrangfer }}{0.45 * f c i}-1<0$

- Eworking $-1<0$

- $\frac{M u}{M u l i m}-1<0$

Mulimail deficetion

- $\overline{\text { Permigsible deflection }}-1<0$

- $\frac{\text { te }}{\text { temax }}-1<0$

where,

$\mathrm{Zb}=$ Section modulus of girder

$\mathrm{Mq}=$ Bending moment due to live load

$\mathrm{Mg}=$ Bending moment due to dead loads

$\mathrm{fbr}=(\mathrm{fctxnl}-\mathrm{ftw})$

$\mathrm{fct}=$ Allowable compressive stress in concrete at initial transfer of prestress

$\mathrm{ftw}=$ Allowable tensile stress in concrete under service loads $\mathrm{nl}=$ Reduction factor for loss of prestress or loss ratio

Zprovided=Section modulus of provided section

Etrans $=$ Stress at transfer

$\mathrm{fck}=$ Characteristic cube strength of concrete

$\mathrm{Mu}=$ Ultimate moment required

Mulim=Ultimate moment carrying capacity of provided section

$\mathrm{Tc}=$ Critical shear stress of the section

Tcmax $=$ Maximum permissible critical shear stress of the section

\section{Optimization Technique}

\subsection{Introduction}

Sequential linear programming is used to solve non-linear optimization problems. In this method originally non-linear programming problem is linearized by using first order Taylors expansion about present design vector. The new design vector is obtained by solving the linear programming problem, which was originally non-linear programming problem. The same procedure continuous till optimum is reached

\section{Procedure for improved move limit method of sequential linear programming}

Step by step procedure for improved move limit method of SLP is as explained bellow:

i) Select the initial feasible design point $\mathrm{X}$ and initial move limit M. Set $\mathrm{K}=1$.

ii) Linearise the constraints and objective function with respect to design point

iii) Impose initial move limit as additional constraints $\mid \mathrm{X}-$ $\mathrm{Xk}|\leq| \mathrm{Mk} \mid$.

iv) After reducing the non linear programming to linear programming problem. Next step is to solve the linear programming problem to get new design point $\mathrm{Xk}^{*}$

v) Check whether new design point $\mathrm{Xk}^{*}$ is in feasible region. If not go to step (viii). vi) Check is there improvement in objective function? if no go to step ix).

vii) Check whether termination criteria are satisfied. Termination criteria are.

a) $\frac{\mathrm{f}\left(\mathrm{X}^{*}\right)-\mathrm{f}(\mathrm{Xk})}{\mathrm{f}(\mathrm{X} 1)} \leq \mathrm{E}^{\mathrm{E}} 1$ b) $\frac{x^{*} 1-x i k}{x i 1} \leq{ }^{\mathrm{E}} 2$ for $\mathrm{i}=1,2 \ldots \mathrm{n}$ where $\varepsilon^{x} 1$ and $\varepsilon_{2}^{x}$ are predefined small quantities. If all the above conditions are satisfied, optimum is reached. Terminate thesearch and print the results.

viii) Steer the design vector to feasible region in the direction $\mathrm{S}=\operatorname{Vgj}(\mathrm{X})$. where $\mathrm{j}$ is the most violated constraint by step

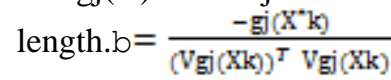

Check whether the steered point is in feasible region. If not repeat the same procedure to steer it to feasible region.Incase the feasible region is not reached even after considerable attempts calculate afresh derivatives and use them to steer tofeasible region. After getting design vector to feasible region take it as $\mathrm{Xk}+1$ and go to step (iv).

ix) If there is no improvement in objective function the direction $\mathrm{S}=\mathrm{Xk}-\mathrm{Xk}$ is correct but step length is large. Hence step length is resorted by quadratic interpolation. Instead of directly going for quadratic interpolation, check Xnew $=\mathrm{Xk}+1$ after steering to feasible region, check if direction $\mathrm{S}=\mathrm{X} \_\mathrm{k}$-Xkis not usable. first carry out the quadratic interpolation between $\mathrm{Xk}$ and $\mathrm{Xk}$ then steer the point to feasible region. Take new point as $\mathrm{Xk}+1$ and go to step vi). For quadratic interpolation

$$
\begin{aligned}
& \mathrm{a}=\frac{\mathrm{f}^{T}(X) S}{\mathrm{f}(\mathrm{Xnew}))-\mathrm{f}(\mathrm{Xk})-\mathrm{Df}^{T}(\mathrm{X} 1) \mathrm{S}} \\
& \text { and take } \mathrm{Mk}+1=\mathrm{a}^{*} \mathrm{Mk}
\end{aligned}
$$

Flow chart of improved move limit with SLP is shown in the figure-4

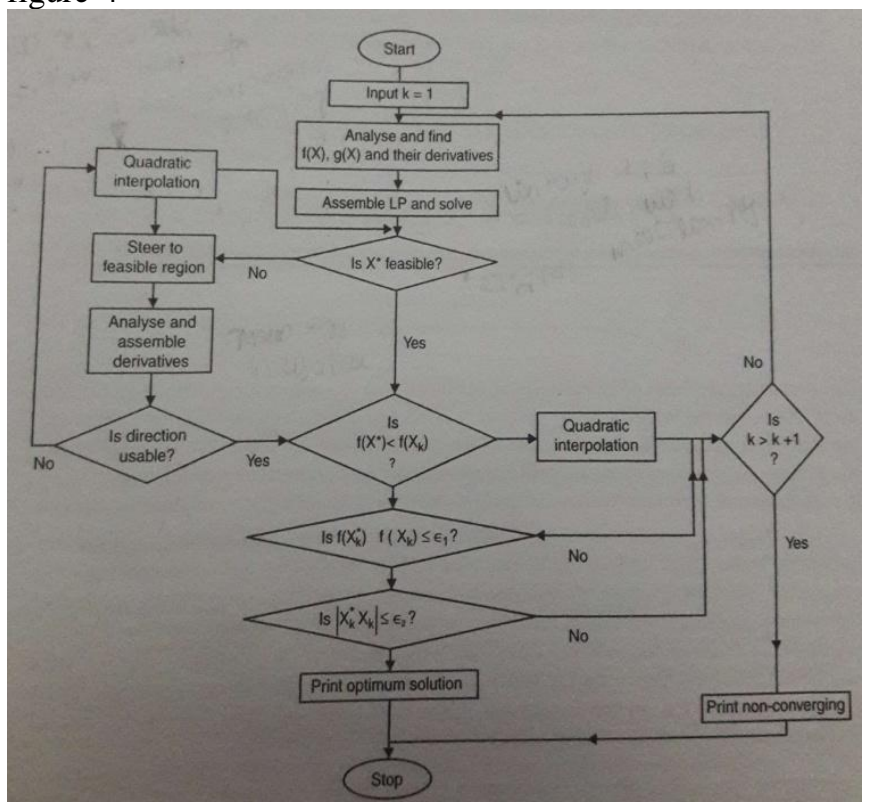

Figure 4: Flow chart of improved move limit method with SLP

\section{Introduction to optimizer}

Optimizer is built on bases of sequential linear programming with improved move limit method consist of five 


\section{International Journal of Science and Research (IJSR) \\ ISSN (Online): 2319-7064 \\ Index Copernicus Value (2015): 78.96 | Impact Factor (2015): 6.391}

subroutines, namely FUNCT, DERIV, SIMPLX, QUADIN and STEER with a analyzer subroutine called 'PROBLM'. All the subroutines perform a unique and specific purpose.

\section{1) FUNCT}

FUNCT subroutine calls the analyzer directly or through subroutine DERIV for function evaluation alone or for both function and derivative evaluation. This subroutine even checks the termination criteria for both maximum number of function and derivative evaluation.

\section{2) DERIV}

DERIV subroutine is called when derivatives of objective function and constraints with respect to design point is to be evaluated. DERIV subroutine is called by FUNCT wherever necessary.

\section{3) SIMPLX}

After linearizing of objective function and constraints through DERIV subroutine, SIMPLX subroutine is called through main program to assemble and solve the linear programming problem by simplex method.

\section{4) QUADIN}

If objective function obtained is higher than present value after solving linear programming problem, QUADIN subroutine will be called through main program to get improved design points which lead to objective function less than or equal to present value.

\section{5) STEER}

When starting point or any other design point after linear programming is in infeasible region then STEER subroutine is called by main program to steer the design point to feasible region.

\section{6) PROBLM}

PROBLM subroutine act as a connector between optimizer and design program or problem to be optimized.

Following are the inputs required for the optimizer:

1) No of variables.

2) No of constraints.

3) Initial move limits.

4) Lower limits on variables.

5) Upper limits on variables.

6) Step length for calculating derivatives.

7) Maximum number of function evaluation.

8) Maximum No of derivative evaluation.
9) Negligible values on variables, objective functions, constraint violation.

10) Initial design points.

\subsection{Optimization of Pre-Cast Post-Tensioned Concrete Deck Type Box Girder Bridge}

After the mathematical formulation of optimization problem, design program is developed and tested. Next step is to test the optimizer and connect the design program to optimizer. In this problem detailed study on process of Optimization of Pre-Cast Post-Tensioned Concrete Deck Type Box Girder Bridge is carried for span $40 \mathrm{~m}$ with carriage way width of $7.5 \mathrm{~m}$, and M40 grade of concrete and Fe415 grade of steel.

- No of variables - 4

- No of constraints -6

- Initial move limits -0.06,0.06,0.06,0.06

- Lower limits on variables:1.50,0.26,0.26,0.3

- Step length for calculating derivatives - 0.001

- Maximum number of function evaluation - 1000

- Maximum No of derivative evaluation - 1000

- All the negligible values - 0.001 (Negligible value for difference in objective function, variables, constraints from subsequent iterations)

Design program developed is connected to sequential linear programming based optimizer with the inputs as mentioned. Optimizer proceeded for number of function and derivative evaluation till the optimum point is reached. Using M40 gradeconcrete and Fe415 steel optimization is carried out for $40 \mathrm{~m}$ span.

Table 2: progress of optimization

\begin{tabular}{|c|c|c|c|c|c|}
\hline Iteration No. & $\mathrm{X} 1$ & $\mathrm{X} 2$ & $\mathrm{X} 3$ & $\mathrm{X} 4$ & $\begin{array}{c}\text { Objective function } \\
\text { (Rupees in Lakhs) }\end{array}$ \\
\hline Initial points & 2.000 & 0.30 & 0.30 & 0.30 & 13.699 \\
\hline 1 & 1.750 & 0.27 & 0.27 & 0.30 & 13.058 \\
\hline 2 & 1.745 & 0.26 & 0.26 & 0.30 & 12.943 \\
\hline 3 & 1.743 & 0.26 & 0.26 & 0.30 & 12.930 \\
\hline Optim. & 1.743 & 0.26 & 0.26 & 0.30 & 12.930 \\
\hline
\end{tabular}

where:

$\mathrm{X} 1=$ Over all depth of box girder in $\mathrm{m}$

$\mathrm{X} 2=$ Thickness of top flange in $\mathrm{m}$

$\mathrm{X} 3=$ Thickness of bottom flange in $\mathrm{m}$

$\mathrm{X} 4=$ Thickness of web girder in $\mathrm{m}$

Table 3: Comparison of Optimum variables from various starting points

\begin{tabular}{|c|c|c|c|c|c|c|c|c|c|}
\hline \multicolumn{4}{|c|}{ Starting Points } & \multirow{2}{*}{$\begin{array}{l}\text { Cost Rupees } \\
\text { in Lakhs }\end{array}$} & \multicolumn{4}{|c|}{ Optimum Points } & \multirow{2}{*}{$\begin{array}{c}\text { Cost Rupees } \\
\text { in Lakhs }\end{array}$} \\
\hline $\mathrm{X} 1$ & $\mathrm{X} 1$ & X3 & $\mathrm{X} 4$ & & $\mathrm{X} 1$ & $\mathrm{X} 2$ & X3 & $\mathrm{X} 4$ & \\
\hline 1.85 & 0.28 & 0.28 & 0.30 & 13.278 & 1.736 & 0.26 & 0.269 & 0.30 & 13.01 \\
\hline 1.90 & 0.28 & 0.26 & 0.30 & 13.185 & 1.80 & 0.27 & 0.27 & 0.30 & 13.17 \\
\hline 2.00 & 0.30 & 0.30 & 0.30 & 13.69 & 1.743 & 0.26 & 0.26 & 0.30 & 12.93 \\
\hline 2.00 & 0.31 & 0.30 & 0.30 & 13.764 & 2.50 & 0.26 & 0.26 & 0.30 & 13.14 \\
\hline 2.10 & 0.27 & 0.26 & 0.30 & 13.265 & 2.35 & 0.26 & 0.26 & 0.30 & 11.88 \\
\hline 2.20 & 0.26 & 0.27 & 0.30 & 11.82 & 2.09 & 0.26 & 0.265 & 0.30 & 11.74 \\
\hline 2.30 & 0.30 & 0.32 & 0.30 & 12.546 & 2.05 & 0.26 & 0.28 & 0.30 & 11.92 \\
\hline 2.40 & 0.26 & 0.27 & 0.30 & 11.983 & 2.40 & 0.26 & 0.26 & 0.33 & 11.85 \\
\hline 2.50 & 0.27 & 0.27 & 0.30 & 12.139 & 2.20 & 0.27 & 0.27 & 0.30 & 11.80 \\
\hline
\end{tabular}


International Journal of Science and Research (IJSR)

ISSN (Online): 2319-7064

Index Copernicus Value (2015): 78.96 | Impact Factor (2015): 6.391

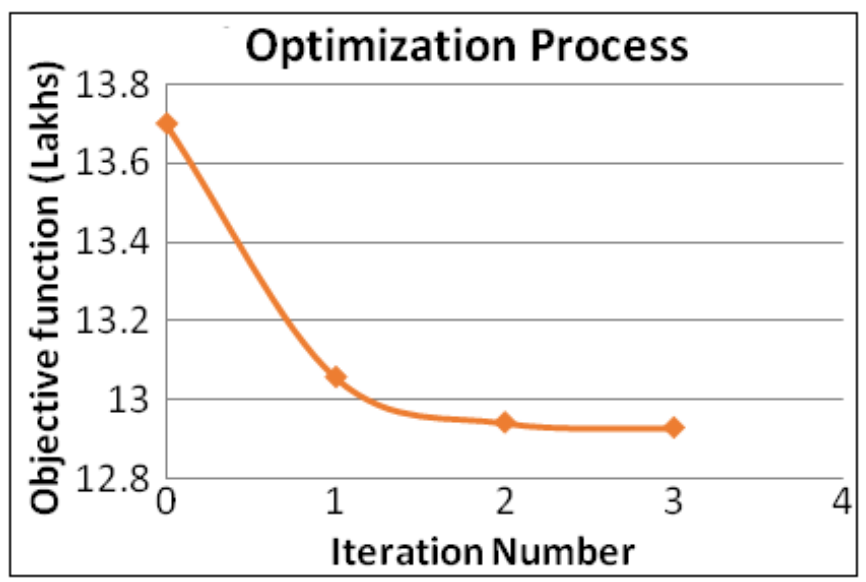

Figure 5: Variation of objective function with Corresponding iterations.

From the Table- No 3 the problem was started with different starting points it resulting in different optimum points. Hence we can say that there a number of local optimumpoints.

\section{Results and Discussion}

\subsection{Effect of change in grade of concrete and steel.}

Cost of the structure will be affected by grade of the concrete as well as steel. In this section effect of change in grade of the concrete and steel on optimum variables and cost of the structure is discussed

Table 5: Rates for different grade of concrete

\begin{tabular}{|c|l|l|l|l|}
\hline Grade of concrete in N/mm2 & M40 & M45 & M50 & M60 \\
\hline Rate in rupees per cubic meter & 6000 & 6500 & 7000 & 8000 \\
\hline
\end{tabular}

Table 6: Rates for different grade of steel

\begin{tabular}{|l|l|l|}
\hline Grade of steel in N/mm2 & $\mathrm{Fe} 415$ & $\mathrm{Fe} 500$ \\
\hline Rate in rupees per ton & 40000 & 45000 \\
\hline
\end{tabular}

Table 7: Variation of optimum cost with change in grade of concrete:

\begin{tabular}{|c|c|c|c|c|}
\hline [For Fe415Steel] & \multicolumn{4}{|c|}{ Total optimum cost(Rupees in Lakhs ) } \\
\cline { 2 - 5 } Grade of concrete & M40 & M45 & M50 & M60 \\
\hline Span in meter & & & & \\
\hline 20.0 & 4.18 & 4.36 & 4.60 & 4.98 \\
\hline 25.0 & 5.50 & 5.76 & 6.02 & 6.54 \\
\hline 30.0 & 7.50 & 8.04 & 8.23 & 8.96 \\
\hline 35.0 & 9.98 & 10.32 & 10.65 & 11.35 \\
\hline 40.0 & 11.74 & 12.12 & 12.54 & 13.35 \\
\hline
\end{tabular}

Table 8: Optimum cost for different grade of concrete and span.

\begin{tabular}{|c|c|c|c|c|}
\hline [For Fe500 Steel] & \multicolumn{4}{|c|}{ Total optimum cost(Rupees in Lakhs) } \\
\cline { 2 - 5 } Grade of concrete & M40 & M45 & M50 & M60 \\
\hline Span in meter & & & & \\
\hline 20.0 & 4.20 & 4.39 & 4.67 & 5.06 \\
\hline 25.0 & 5.56 & 5.81 & 6.07 & 6.590 \\
\hline 30.0 & 7.56 & 8.18 & 8.27 & 9.05 \\
\hline 35.0 & 10.05 & 10.38 & 10.72 & 11.42 \\
\hline 40.0 & 11.83 & 12.22 & 12.58 & 13.45 \\
\hline
\end{tabular}

By referring to Table-No $7 \& 8$

- Total cost of the structure increases with increase in grade of concrete

By referring to Table-No $7 \& 8$ Total cost of the structure slightly increases with increase in grade of steel.

\subsection{Cost ratio}

Cost ratio is defined as ratio of cost of unit volume of steel to the cost of unit volume of concrete. Cost of steel and concrete vary with time, hence parametric study is carried out for different cost ratios.

Study is carried out for carriage way width of $7.5 \mathrm{~m}$. Following are the inputs for each cost ratio.

- Characteristics strength of concrete- $40 \mathrm{~N} / \mathrm{mm} 2$

- Characteristics strength of steel- $415 \mathrm{~N} / \mathrm{mm} 2$

- Span- 40m

Parametric study is conducted for different cost ratios, various span and grade of concrete and steel as follows.

Table 9: Optimum points for different cost ratios

\begin{tabular}{|c|c|c|c|c|c|}
\hline Sl.No & Cost & \multicolumn{4}{|c|}{ Optimum Points } \\
\cline { 3 - 6 } & Ratio & $\mathbf{X 1}$ & $\mathbf{X 2}$ & $\mathbf{X 3}$ & $\mathbf{X 4}$ \\
\hline 1. & 50 & 2.09 & 0.26 & 0.265 & 0.30 \\
\hline 2. & 60 & 2.09 & 0.26 & 0.265 & 0.30 \\
\hline 3. & 70 & 2.09 & 0.26 & 0.265 & 0.30 \\
\hline 4. & 80 & 2.09 & 0.26 & 0.265 & 0.30 \\
\hline 5. & 90 & 2.09 & 0.26 & 0.265 & 0.30 \\
\hline 6. & 100 & 2.09 & 0.26 & 0.265 & 0.30 \\
\hline $\mathbf{7 .}$ & $\mathbf{5 9 . 0 5}$ & 2.09 & 0.26 & 0.265 & 0.30 \\
\hline
\end{tabular}

From table No9it is clear that for cost ratio between 50 to 100 there is no change in the design variables

Table 10: Optimum cost and optimum points for M40 grade of concrete and Fe 415 steel for different spans

\begin{tabular}{|c|c|c|c|c|c|c|c|c|c|c|}
\hline \multirow{2}{*}{$\begin{array}{c}\text { Span in } \\
\text { Meter }\end{array}$} & \multicolumn{4}{|c|}{ Starting Points } & Cost (Rupees in & \multicolumn{4}{|c|}{ Optimum Points } & Cost \\
\cline { 2 - 3 } Rupees in Lakhs \\
\hline 20 & 2.20 & 0.26 & 0.26 & 0.30 & 5.25 & 1.54 & 0.267 & 0.26 & 0.3 & 4.98 \\
\hline 25 & 1.80 & 0.26 & 0.26 & 0.30 & 7.23 & 2.05 & 0.26 & 0.26 & 0.33 & 6.59 \\
\hline 30 & 2.20 & 0.28 & 0.28 & 0.30 & 9.230 & 1.86 & 0.28 & 0.28 & 0.3 & 8.96 \\
\hline 35 & 2.00 & 0.29 & 0.29 & 0.30 & 10.548 & 1.734 & 0.26 & 0.26 & 0.3 & 9.98 \\
\hline 40 & 2.20 & 0.26 & 0.27 & 0.30 & 11.82 & 2.09 & 0.26 & 0.26 & 0.3 & 11.74 \\
\hline
\end{tabular}

\section{Volume 6 Issue 7, July 2017 www.ijsr.net}




\section{International Journal of Science and Research (IJSR) \\ ISSN (Online): 2319-7064}

Index Copernicus Value (2015): 78.96 | Impact Factor (2015): 6.391

Table 11: Optimum variables with different span

\begin{tabular}{|r|c|c|c|c|c|}
\hline Sl.No & Span in meter & \multicolumn{4}{|c|}{ Optimum design Variables } \\
\hline & & $\mathrm{X} 1$ & $\mathrm{X} 2$ & $\mathrm{X} 3$ & $\mathrm{X} 4$ \\
\hline 1. & 20.0 & 1.54 & 0.267 & 0.26 & 0.3 \\
\hline 2. & 25.0 & 2.05 & 0.26 & 0.26 & 0.33 \\
\hline 3. & 30.0 & 1.86 & 0.28 & 0.28 & 0.3 \\
\hline 4. & 35.0 & 1.734 & 0.26 & 0.26 & 0.3 \\
\hline 5. & 40.0 & 2.09 & 0.26 & 0.265 & 0.3 \\
\hline
\end{tabular}

Referring to the Table-11following observations can be made:

- It can be seen that variation of optimum dimensions for thickness of top and bottom flange and thickness of web girder for different span of are almost linear.

Table 12: L/D ratio for various span of PSC Box Girder Bridge

\begin{tabular}{|r|c|c|c|}
\hline S1.No & Span in meter & X1(D) & L/D ratio \\
\hline 1. & 20.0 & 1.54 & 12.987 \\
\hline 2. & 25.0 & 2.05 & 12.195 \\
\hline 3. & 30.0 & 1.86 & 16.129 \\
\hline 4. & 35.0 & 1.734 & 20.185 \\
\hline 5. & 40.0 & 2.09 & 19.139 \\
\hline
\end{tabular}

Following observations can be made from the Table-No 12 - For a span up to $25 \mathrm{~m}$ optimum depth is $\left(\frac{1}{12}\right)^{\text {th }}$ of span. For a span of $35 \mathrm{~m}$ onwards it is $\left(\frac{1}{20}\right)^{\text {th }}$ of span

Table 13: Various ratios for optimum variables with different span

\begin{tabular}{|c|c|c|c|c|c|c|c|c|c|}
\hline \multirow{2}{*}{$\begin{array}{c}\text { Span in } \\
\text { meter }\end{array}$} & \multicolumn{1}{|c|}{ Optimum design Variables } & \multicolumn{5}{|c|}{ Ratios } \\
\hline & $\mathrm{X} 1$ & $\mathrm{X} 2$ & $\mathrm{X} 3$ & $\mathrm{X} 4$ & $\mathrm{x} 1 / \mathrm{x} 2$ & $\mathrm{x} 1 / \mathrm{x} 3$ & $\mathrm{x} 1 / \mathrm{x} 4$ & $\mathrm{x} 2 / \mathrm{x} 4$ & $\mathrm{x} 3 / \mathrm{x} 4$ \\
\hline 20 & 1.454 & 0.26 & 0.26 & 0.3 & 5.768 & 5.923 & 5.133 & 0.890 & 0.867 \\
\hline 25 & 1.98 & 0.26 & 0.26 & 0.3 & 7.885 & 7.885 & 6.212 & 0.788 & 0.788 \\
\hline 30 & 1.734 & 0.26 & 0.26 & 0.3 & 6.643 & 6.643 & 6.200 & 0.933 & 0.933 \\
\hline 35 & 2.26 & 0.26 & 0.26 & 0.3 & 6.669 & 6.669 & 5.780 & 0.867 & 0.867 \\
\hline 40 & 2.09 & 0.26 & 0.265 & 0.30 & 8.038 & 7.887 & 6.967 & 0.867 & 0.883 \\
\hline
\end{tabular}

\section{Conclusion}

1) Optimization of Pre-Cast Post-Tensioned Concrete Deck Type Box Girder Bridge can be carried satisfactorily by using sequential linear programming with improved move limit method..

2) For the design of the span of $20 \mathrm{~m}$ to $40 \mathrm{~m} \mathrm{M} 40$ grade of concrete and Fe 415 steel(For untensioned reinforcement) is recommended.

3) For the cost ratio for the concrete in the range of 50 to 100 the optimum variables remains same.

4) For the cost ratio for the steel in the range of 150 to 200 the optimum variables remains same.

\section{Reference}

[1] Ajithkumar R and Dr. Dattatreya(2015) "study on structural behavior and design of typical single cell posttensioned concrete box girder bridge."

[2] Aswini M.G, V,Nvazirani, N.RAJGIPALAN "Design of Concrete BridgeBridge super structure".

[3] Bhavikatti S.S., "Fundamentals of optimum design in engineering", $2^{\text {nd }}$ Edition, New Academic Science limited London, 2008.
[4] Bhivgade." P.R Analysis and design of prestressed concrete box girder bridge."

[5] Johnsons victor D "ESSENTIALS OF BRIDGE ENGINEERING

[6] IRC: 18 - 2000 " DESIGN CRITERIA FOR PRESTRESSED CONCRETE ROAD BRIDGES (POST-TENSIONED CONCRETE)" THE INDIAN ROADS CONGRESS.

[7] IRC: 6- 2000 "STANDARD SPECIFICATIONS AND CODE OF PRACTICE FOR ROAD BRIDGES"THE ROAD CONGRESS.

[8] IRC: 6- 2014 "STANDARD SPECIFICATIONS AND CODE OF PRACTICE FOR ROAD BRIDGES"THE ROAD CONGRESS.

[9] IRC 21-2000 STANDARD SPECIFICATIONS AND CODE OF PRACTICE FOR ROAD BRIDGES'THE ROAD CONGRESS

[10] IRC112-2011CODE OF PRACTICE FOR CONCRETE ROAD BRIDGES.

[11]IS: 1343 - 2012 “CODE OF PRACTICE FOR PRESTRESSED CONCRETE" INDIAN STANDARDS.

[12]IS 6006 (1983): uncoated stress relieved strand for prestressed concrete [CED 54: Concrete Reinforcement]

[13] IS456-2000, \Plain and reinforced concrete - Code of practice", Bureauof Indian Standards, New Delhi.

[14] Jagadeesh T R, M.A. Jayaram (2012) Design of Bridge Structures, PHI Learning Private Limited Second Edition 2012

[15] Krishna Raju "DESIGN OF BRIDGES" OXFORD \& IBH PUBLISHING CO. PVT. LTD.

[16] Krishna Raju N. (1995). Prestressed Concrete, Tata McGraw- Hill Publishing company Limited, New Delhi

[17] MohmmedA.Al-Osta .Abdul K. Azad. Husain J.AlGahtani(2012):"Optimization of Continuous Post Tensioned Concrete Bridge Girder of Non Uniform Depth.

[18] Phani Kumar. Ch. ,S.V.V.K. Babu., D Aditya Sai Ram(2016) "analysis and Design of prestressed box girder bridge by IRC 112-2011

[19] Raina, V.K. (1994). Concrete Bridge Practice-Analysis, Design and Economics, McGraw- Hill Publishing Company Limited, New Delhi

[20] Schedule of rates 2016-2017 public works, ports \& inland water transport department, north zone, Dharwad.

\section{Author Profile}

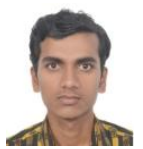

Nagaraj Nayak received the B.E. degrees in Civil Engineering from SDM College of Engineeringand Technology Dharwad in 2014, later he has worked in the Sri Sai Consultants (2014-2015) presently pursuing his masters in structure from K.L.E Technological University Hubballi, Karnataka(2015-2017).

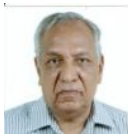

Dr. S.S. Bhavikattistudied at BVB College of Engineering and Technology, Hubli for his BE (Civil) degree and graduated from Karnataka University, Dharwad in 1963 He secured M.E. degree in Structural Engineering in 1967 from University of Roorkee, Roorkee (presently IIT Roorkee) and Ph.D. degree in 1977 from IIT Delhi. He served NITK in different capacities. After retiring from NITK in 2001 he served at SDM College of Engineering and Technology, Dharwad. He then served RYMEC, Bellary as Principal. For the last 10 years he is working as Emeritus Professor at KLE Technological 


\section{International Journal of Science and Research (IJSR) \\ ISSN (Online): 2319-7064}

Index Copernicus Value (2015): 78.96 | Impact Factor (2015): 6.391

University (Formerly BVB College of Engineering and

Technology). He has published 65 technical papers and 61 books.

He has guided 78 students for M.Tech dissertation and 6 students for Ph. D. 